Article

\title{
Sámi indigenous(?) Religion(s)(?)—Some Observations and Suggestions Concerning Term Use
}

\author{
Konsta Kaikkonen
}

Department of Archaeology, History, Cultural Studies and Religion, University of Bergen, 5007 Bergen, Norway; konstakaikkonen@gmail.com

Received: 30 July 2020; Accepted: 18 August 2020; Published: 23 August 2020

Abstract: When writing about politically and culturally sensitive topics, term use is of great relevance. Sámi religion is a case in point. Words organise and create the world around us, and labels have direct consequences on how religious phenomena are perceived. Even labelling a phenomenon or an action "religious" carries certain baggage. Term use is, of course, easier when writing about historical materials and describing rituals whose practitioners have been dead for centuries. Nonetheless, contemporary practitioners of age-old rituals or people who use ancient symbols in their everyday lives often see themselves as carriers of old tradition and wish to identify with previous generations regardless of opinions that might deem their actions as "re-enacting", "neoshamanism", or "neopaganism". If, for example, outsider academics wish to deem modern-day Indigenous persons as "neo"-something, issues of power and essentialism blend in with the discourse. This paper critically explores terms used around the Sámi religion in different time periods and attempts to come to suggestions that could solve some of the terminological problems a student of modern practitioners of indigenous religions inevitably faces.

Keywords: indigenous religion; religion; terminology; indigenous terms; translation; shamanism

\section{Introduction: Why Care about What Terms Are Used?}

The Sámi are an Indigenous people living in Sápmi, an area stretching across the state borders of Norway, Sweden, Finland, and Russia. They have at least since the 16th century been subjected to coercive efforts to eradicate their indigenous belief systems by the colonising powers of Church and State in the said countries (see the introduction to this special issue; for an overview of the reconciliation processes, see Helga West's article in this issue). This has resulted in a transgenerational trauma, which some representants of the community have dealt with by turning to their peoples' age-old beliefs and practices in their everyday spiritual or religious life; others with silence and denial; some by using indigenous customs, symbols, and stories as sources of interest and inspiration. For non-Sámi outsiders it is important to be as respectful to all these various approaches as possible, and in this article, I will discuss some of my own observations and suggestions concerning scholarly terms in English academic writing.

I have decided not to single out any specific academic uses or users of different terms I criticise, rather basing myself on my own reflections and observations, as well as on several formal and informal private discussions with colleagues and students on matters concerning terminology. The matters that I discuss here have come to my attention largely through the work of the supervisor of my doctoral thesis Håkan Rydving, whose particularistic, attentive to detail, and terminologically rigorous approach has inspired a new generation of scholars of indigenous religions, among them Jelena Porsanger, Bjørn Ola Tafjord, and Olle Sundström. I consider myself as belonging to the same group of scholars and have been inspired by all of the above, having on this basis developed my own terminological approach to Sámi indigenous religion for my doctoral thesis (Kaikkonen forthcoming)—a source critical inquiry 
into textual descriptions of Sámi ritual specialists. I found it of importance to develop a terminology that attempted to base on Sámi notions instead of those applied from the outside for the project, having developed these terminological considerations further in this article.

It should be borne in mind that I am a representative of the outsider group and limited in my expertise on contemporary forms of Sámi religion as well as on Sámi languages, having mainly studied the history of Sámi religion and the related outsider interpretations. I have taken here as my task to discuss problems in term use and formulate some suggestions aspiring towards respectful, yet precise use of terms. I do this from a critically oriented perspective of a historian of religions, inspired by scholars of religion advocating for a particularistic viewpoint and forerunners in particularly Sámi methodology. I explore the topic from a point of view that bases on the frameworks of social constructivism and critical studies of religion, as well as some aspects of translation theory.

As I have demonstrated elsewhere (Kaikkonen 2019, forthcoming), an exoticist fascination towards the age-old beliefs and practices of the Sámi, that existed previous to as well as alongside Christianity, has often focused the interest of majorities in the Nordic states-and beyond-towards the Sámi. This has resulted in several written descriptions of Sámi religion, where the beliefs and practices I have decided in this article to label "Sámi indigenous religion" have been translated according to the prevailing zeitgeist as "witchcraft", "sorcery", or "idolatry" before the 18th century; "superstition" in the times of the Enlightenment; and "nature religion", "primitive religion", or "shamanism" in the 19th and early 20th centuries. Despite changing ideological, religious, and political contexts, this fascination has been a driving force for the outsiders describing and defining Sámi traditions, and if one complies with the basic premises of social constructivism and critical studies, one has to agree that these discourses have shaped, on their part, how the Sámi have been viewed and treated by the non-Sámi majorities.

In order to recognise this historical baggage and come to terms with the problematic foundations of our discipline, us scholars of Sámi religion must attempt to discontinue this interrogative "Western gaze", and I argue - in unison with the Sámi scholar Porsanger (2018) — that we can begin by avoiding terms that are tightly knit to the exoticizing tendencies in Western academia. As the folklorist Fonneland (2018, p. 5) has written about Sámi shamanism, "[i]t matters what we call things." Coming from a particularistic point of view and conforming with arguments made by scholars such as Rydving (2011) and Porsanger (2018), I find that speaking about "Sámi shamanism" changes things in introducing a theory-laden, generalising, and exoticising concept to the already biased and one-sided textual sources we have to deal with. Or as Atkinson (1992, p. 308) put the concerns of cultural anthropologists against using this term, "The category simply does not exist in a unitary and homogeneous form, even within Siberia and Central Asia-the putative homeland of 'classical shamanism"'.

Even though one would agree with arguments postulating an empirically observable phenomenon of "shamanism" - such as those made by Harner and his shamanistic followers on one hand, and the likes of Winkelman (2000) who argue for a neurophysiological unity behind religious experiences among the world's "shamanistic" cultures on the other-one is left with the same questions and critiques when making a translation of non-Western cultural phenomena into the academic concept "shamanism". Even though there would exist a phenomenon called "shamanism" "out there", outside of the "Western" imagination, the concept itself is socially constructed, and if used uncritically it irons out differences between all "shamanistic" cultures and simply sees them as sides of the same phenomenon. Reversely, starting instead with local, indigenous concepts such as the Sámi term noaidevuohta-derived from the trade of one type of Sámi ritual specialist, noaidi-proposes a more particularistic type of approach. ${ }^{1}$

1 Noaidevuohta in North Saami comprises of two different words; the word for a type of ritual specialist, noaidi (with corresponding words in not only all the Sámi languages but also e.g., noita in Finnish and najt in Mansi) and the suffix -vuohta, which can be roughly translated as '-hood' or '-dom'. For a more thorough discussion on the word's uses, see (Kaikkonen 2019, forthcoming). 
For example, if one starts a research project about Sámi shamanism in the 17th and 18th centuries one would probably come to different hypotheses and conclusions than if one would start a research project about Sámi noaidevuohta; the former would probably take as its starting point theories of circumpolar or global shamanism and make comparisons between the Sámi and Siberian "shamanistic" peoples, while the latter might focus on particularly Sámi ritual specialists and start with culture-specific comparisons between different Sámi sources.

I also agree with what the Finnish historian of religions Sjöblom (2002, p. 128) writes about term use, and use his observations as a basis for the approach I have taken in this article:

The role played by heuristic terms in ethnographic description is highly controversial. The chosen term is always based on the theory-laden assumptions of the scholar providing the description. With his/her choice of term the scholar can and usually will influence how the scholarly community view the topic, which he/she is describing. Even when the scholar strives to produce as reliable and truthful a description of his/her research as possible, the fact remains that heuristic terms only seldom-if ever-cover exactly the same semantic space as the emic concepts they are describing.

Sjöblom's observations show that the use of etic, heuristic terms leaves plenty of space for interpretations and skewed translations, but that it is also inevitable. It is exactly these interpretations and theory-laden assumptions that I am going to discuss in the following, as I take some of the most common labels used for Sámi religion in academic English into critical consideration. Moving then to discuss the use of Sámi analytical terms, I introduce some of the alternatives that have been used in North Sámi, mainly basing myself on Porsanger's terminological considerations. This discussion is followed by introducing the factor of time, showing that term use is also of great importance for discussing current matters where power and politics come into play. I will especially target the terms "shamanism" and "neoshamanism" in my discussion. I conclude with some observations and suggestions for term use that I hope could advance the rigor and respect with which Sámi religion—both past and present-is discussed academically.

\section{2. "Sámi Indigenous Religion" and Alternate Terms in Historical Scholarship}

There are numerous terms used for what I have chosen in this paper to call "Sámi indigenous religion". Some of the suggested labels in English that are rarely used today were "paganism", "heathen religion", and "primitive religion", whereas contemporary scholars often talk about "tribal religion", "nature religion", "oral religion", "ethnic religion", "pre-Christian religion", "non-Christian religion", or simply label the whole system of beliefs and practices as "animism", or indeed "Sámi shamanism", as the English Wikipedia does. ${ }^{2}$ Sometimes words like "world view", "mentality", or "spirituality" are used in order to avoid the problematised term "religion". All these labels inevitably carry theoretical, historical, religious, and colonial baggage-some heavier than others. In this section, I will problematise the most common terms used in historical studies of Sámi religion, basing myself on a critical and historically oriented approach and following a rough division into three different ways of speaking about Sámi indigenous religion in the academia.

\subsection{Terms that Approach Sámi Religion by What It Is Not}

First, I will discuss the problems arising from dichotomies that are created by setting Sámi indigenous religion and Christianity directly as opposing polarities. The contemporarily nearly extinct terms "paganism" and "heathen religion", as well as the very much extant "pre-Christian" and "non-Christian", all suffer from this implicit or explicit polarity. 
It is commonly accepted today that "pagan" and "heathen" refer to the non-Christian, non-Jewish, and non-Muslim populace, and moreover have a connotation of uncivilised, immoral, or barbarous customs. ${ }^{3}$ Both terms are today considered pejorative and their use as etic terms in academic literature, at least in the historically oriented Study of Religions, has lately been uncommon. The history and meaning of these terms are shaped by a contrast to Christianity and "civilization", whatever the latter term might mean for its users. Simultaneously, "paganism" has been adopted as an emic term by several groups who often wish to emphasise the contrast to Christianity and link their practice with pre-Christian customs. ${ }^{4}$

A less pejorative trend has been to refer to "pre-Christian" or "non-Christian" traditions of the Sámi, such as I have myself done previously (Kaikkonen 2019). Having since reviewed my position, I argue that the use of these terms proves challenging in light of the source material we have of Sámi religion, and the interpretations made thereof. If we agree with scholars of Sámi religious history such as Rydving $(2000$, p. 18) who deem the textual material written by missionaries in the 17th and 18th centuries as the most important sources to Sámi indigenous religion, it is impossible to label the phenomena, practices, and beliefs that the sources describe as "non-Christian" or "pre-Christian".

As the historian Rasmussen (2016) has convincingly argued-informed by several previous investigations into the matter-it is only in terms of the pietistic missionaries, their chroniclers, and their views of "correct Christianity" that the Sámi religion encountered in the sources can be labelled non-Christian. Pre-Christian they are, in the strict analytical meaning of the word, not-all of the sources from the 17th and 18th centuries are descriptions of Christian, baptised Sámi and made by theologically trained representatives of the majority cultures who filtered what they heard and saw through a Christian understanding. In addition, it seems that Christianity had spread to Sápmi already in the high Middle ages, several centuries before the most important written sources (Widén 1980; Hansen and Olsen 2013, pp. 315-19).

The most important texts describing Sámi religion in the 17th and 18th centuries are therefore mostly descriptions of Christian Sámi who practiced rituals with influences from both Catholic and Protestant Christianity, as well as from local, indigenous customs, made by Christian non-Sámi. Rasmussen (2016, p. 80), indeed, writes, "Different sources dating from the early modern period indicate that elements of the Catholic faith were incorporated within Sámi culture, even within the Sámi religion; and on the other hand, some elements of the Sámi religion were brought into the Church."

This problem is in line with what Rydving (2010, pp. 39-56) has discussed in relation to interpretations of Sámi drum figures; using the labels "pre-Christian" and "non-Christian" for Sámi religion tends to disregard the Christian influences upon the source material and the few insider explanations, and instead leads to an interpretation where everything that is not in line with Lutheran belief to be of a pre-Christian vestige. The use of these labels entails a pure form of Christianity and a pure form of Sámi indigenous religion, unchanged before the writing of the source material and traceable to times immemorial. Based on what we know from historical sources, the fluidity and interconnectedness between Sámi pre-Christian and Christian religious traditions should instead be emphasised and essentialising notions of pure religious forms cast aside, were we to strive towards using terms which are precise.

To add to the problems of these terms, they define Sámi indigenous religion for what it is not rather than for what it is, continuing the application of a Christian perspective to other, "non-Christian" religions. An emphasis on the difference between pre-Christianity and Christianity in a historical case can, furthermore, be seen to imply a sudden conversion sparked by a religious experience and turning to "the right religion". While this narrative is characteristic of Christian individual conversion stories

3 See, for example, Concise Oxford Disctionary entries "heathen" and "pagan".

4 For a short description of modern "neo-pagans", see Encyclopaedia Britannica's entry on Neo-Paganism <https://www. britannica.com/topic/Neo-Paganism> Accessed 28.7.2020. 
it is hardly applicable to the changing of the religion of an entire people in the past. ${ }^{5}$ This is not the sense that a serious, non-confessional, and historically oriented scholarship on Sámi religion should in my opinion carried in, and the use of terms like "pre-Christian" or "non-Christian" which categorise religions as antonyms to Christianity is, therefore, religiously biased and analytically imprecise.

The same criticism largely goes for words like "syncretism", "assimilation", and "acculturation" that are commonly used for the colonial situation where Sámi religion was gradually and forcefully replaced by more conventional and orthodox forms of Christianity, as seen from the Lutheran point of view. Speaking of syncretism, of course, takes as its starting point the idea of a "pure" Christianity that is universal and not influenced by local customs, and as such is tightly related to the Lutheran critique of Catholicism. The same problematics that we face when speaking of "pre-Christian" and "Christian" Sámi religion are faced by a scholar speaking of "syncretism": the analyst takes the implicit burden of defining "correct" Christianity or non-Christianity when they define something as "syncretistic".

Following Pye's (1994) suggestions of term use, we could rather speak of an assimilation of Christian elements into an indigenous framework before the missionary era, followed by a forceful suppression of the indigenous religion from the public sphere, with a simultaneous continuation of indigenous practices and beliefs in the private life of individuals resulting in a type of synthesis in people's everyday life. This process cannot be simply labelled "syncretism" when analysing the blurry border of "indigenous" and "Christian" influences on Sámi religion as found in the early modern textual sources if one wants to hold an analytically rigorous attitude to one's topic of study and acknowledge the constantly changing and flexible nature of the phenomena we scholars label "religion".

\subsection{Terms that Approach Sámi Religion Typologically}

Similar problems arise with terms like "oral religion" or "nature religion", not to mention the term "primitive religion", as they imply a typology of religions based on a notion of progress. To speak of "nature religion" in English is directly related to the dichotomy that puts "nature" and "culture" at opposite ends of a spectrum. Needless to say, if Christianity is seen as the religion of "culture" and Sámi indigenous religion as a "nature religion", this also has implications towards the other being generally more desirable, advanced, and sophisticated than "natural" religion.

While there are none that deny the close relation of Sámi culture and religion to the natural surroundings, the baggage that follows the nature/culture dichotomy implicit in Western thought places "nature religions" in a certain category, which is almost uniform with the notion of primitivism (Porsanger 2018, p. 149). Even if the word luondduoskkoldat sometimes used of the indigenous religion in North Sámi might not carry these connotations, and indeed relates Sámi religion to its closeness to luonddu—roughly translatable as "nature", "creation", or even "essence"—the English term "nature religion" immediately draws the reader's connotation to a "primitive" Naturmensch. Or would anyone use the label "nature" for the other closely nature-related activities of the Sámi such as "nature transportation", "nature clothing", "nature childrearing", "nature housing", or indeed, "nature culture"?

The dichotomy between "oral religion" and "literary religion" can be criticised from the same grounds, but in addition, this typology is completely lacking in analytical use as each and every religion, regardless of being formulated around sacred texts or not, is transmitted orally across generations and people. This division is also reminiscent of Redfield's "great tradition/small tradition" divide, further developed for the comparative Study of Religions by Juha Pentikäinen, who distinguished between literary world Religions with a capital $\mathrm{R}$ and "folk religions" with a small case $\mathrm{r}^{6}$

5 Rasmussen (2016, p. 79) decides to use the term "integration" instead of the problematic "conversion" when speaking about Sámis becoming part of the "ecclesiastical system".

6 For the most recent application of this idea to Sámi religion, see (Pentikäinen and Pulkkinen 2018, p. 92 f). 
Classifying Sámi indigenous religion as "oral" or "small" while implying Christianity as its "literary", "great" antithesis not only taps upon the above-discussed dichotomies between primitive and advanced as well as Christian and non-Christian religions but is also lacking in analytical strength. Who could, for example, say that the theological views of laymen in Medieval Catholic West Norway were more based on textual traditions than oral and material aspects of religious communication? One could speak of vernacular and textual aspects of a single religion or that of a single group of people in a certain context, but to make typologies based on these aspects is in my view analytically unsound and methodologically outdated.

\subsection{Terms that Approach Sámi Religion as a Situated Category}

A commonly used term that links Sámi religion to the Sámi as a people is "ethnic religion", sometimes also "tribal religion" is used. The latter suffers from similar primitivist understandings as the examples discussed in the previous section, while the previous refers to the religious traditions of an ethnic group, but still holds a connotation of something "heathen" or exotic; the word "ethnic", of course, derives from the Greek word $\tilde{\varepsilon} \theta v o \varsigma$, "nation, tribe, people". Often, however, "ethnic religion" is used as a category of religions that stands opposite to "universalizing" religions such as Christianity, in a similar manner as the division between "oral" and "literary" does. In this sense, the Sámi ethnic religion would be the original religion of the Sámi people, meant as an antonym to the universal Christianity. If used thus as a typology, the category of "ethnic religions" is subject to the same criticisms as the ones discussed above as it implies a process of conversion or advancement from "ethnic" to "universal" religions.

There are, in addition, further analytical and connotational problems with the term "ethnic religion". If one associates the category "ethnic" to practically anything, the Western mind is drawn to exoticism, as pointed out in the Concise Oxford Dictionary (Thompson 1998, p. 463) definition. Terms like "ethnic food" or "ethnic music" do not make one think of Austrian waltzes or French cuisine, but rather something "the other" does, a resource for westerners to tap into and experience exotic things outside of the usual. For me, the word "ethnic religion" does just that; it does not draw one's attention to something familiar, but rather something exotic and "wild".

Furthermore, as has been emphasised by Rydving and others, it is highly problematic to speak of a singular "Sámi religion" in the first place, and adding the label "ethnic" to the mix further accentuates these problems. The fact that Sámi religion was in constant change and not at all homogeneous in time or space-not even mentioning the difficult question of defining Sámi ethnicity in retrospect and from the outside-lades the label "ethnic religion" with serious problems. It irons out the differences between Sámi language and economic groups in space and time, and does not account for the exchange of ideas between the Sámi and non-Sámi populations of Old Norse, Finnish, Lutheran, Catholic, Russian Orthodox, and/or Karelian religious traditions-both written and oral, vernacular as well as "orthodox".

In addition, it essentialises Sámi culture and religion and raises problematic questions such as the following: Was then some form of Sámi religion more "ethnic" than another? Were the reindeer herding inland Sámi, who had less contact with the non-Sámi groups, "purer" practitioners of "ethnic Sámi religion" while the coastal Sámi were so to a lesser extent? Were also the speakers of South Sámi less "ethnic" in their religion than the speakers of, say, Skolt Sámi?

\subsection{Landing on a Compromise: Indigenous Sámi Religion}

Although not without problems, I prefer to use the etic term "indigenous Sámi religion" when speaking of the phenomena that have been labelled as something belonging to the religious sphere in the historical material. As scholars, it is our job to construct and re-construct, create generalisations, and "do violence" to the sources we study, as a pure description is hardly something that would warrant praise and prestige, or indeed funding, in the scholarly world. In my opinion, our job is to be conscious and explicit with the violence we do to our sources, all the while keeping in mind the 
power scholars hold over their topics of study; one great example is the scholar of religions, Tafjord's (2016) observation of how "talking about indigenous religion may change things", as he walks the reader through examples from his fieldwork sites of how scholarly categories create and change the indigenous traditions we study.

Using the word "indigenous" as an adjective together with the word "religion" is not without problems, as Tafjord $(2013,2017)$ has convincingly shown and identified at least nine different uses—or "language games" - related to the term "indigenous religion" and its plural form. In the next, I will discuss some of the problems with that term and how to possibly overcome them.

The Sámi are almost universally recognised as an Indigenous people. When we speak of Indigenous peoples, it is most often as defined by the ILO convention 169 (Article 1) as "peoples in independent countries who are regarded as indigenous on account of their descent from the populations which inhabited the country, or a geographical region to which the country belongs, at the time of conquest or colonisation or the establishment of present state boundaries and who, irrespective of their legal status, retain some or all of their own social, economic, cultural and political institutions", that also self-identify as "Indigenous'". 7 Tafjord $(2013,2017)$ has argued that using the term "Indigenous" in this sense as an attribute to "religion" surfaces several problems, leading, for example, to implicit politically charged uses or typologies that follow the problems pointed out earlier. If "Indigenous religions" is identified as a universal category as "the religion of Indigenous peoples" it irons out the differences between all the traditions put under that label and carries political or typological implications.

Tafjord (2013, p. 230) points out that the category "indigenous religion" used in the singular as an emic category by the Indigenous peoples themselves becomes a political tool, “Far from representing precise and unambiguous scholarly language, this schematic use of the category contributes in blurring the boundaries between politics and scholarship, between activism and academic work, and between religionising and analysing."

One way of avoiding the problem of mixing the discourse on indigenous religion(s) with Indigenous politics and the global Indigenous movement could be to employ categories such as "endemic", "native", or "autochthonous" when speaking of Sámi religion. These, however, also suffer from problems: "endemic" (an antonym of pandemic) relates to illness, which at least for me is an unwanted analogy; "native" partly suffers from the same problems as "ethnic" and "tribal"; and "autochthonous" means more or less the same as "indigenous", but is of Greek origin instead of Latin. Difficult to pronounce and spell, I have decided to not add "autochthonous" into my vocabulary. I have played around with these terms, but have still landed on using the term "indigenous religion" in a specific, carefully defined way. I have tried to separate the discourse related to Indigenous peoples and Indigenous politics by capitalising the first letter of the word in these cases, and the discourse related to "indigenous religions" and "indigenous words" as situated categories by using the small case letter.

Indeed, if we use the term "indigenous religion" in the singular, of a carefully defined and problematised historical situation, as a "historically and geographically contingent relational concept" (Tafjord 2017, p. 39), its use becomes clearer when discussing encounters between different religions. This is the use in which, for example, Rydving and myself have employed the term in connection to the Sámi religion. It is used for the religious traditions of the Sámi in a situation where they were described by Lutheran missionaries—-the very missionaries responsible for its eradication, a process tightly related to colonial aspirations by the state powers.

It should be noted that "indigenous Sámi religion" used in this sense is not completely free of the problems stated in the previous subchapters-a contrast to Christianity, typology, and essentialism. As "indigenous" is an autonym of "foreign" or "exogeneous", its use in the Sámi case contrasts it with the "exogeneous" Christianity, opening up the question of a "pureness" of the indigenous religion 
encountered by the Lutheran missionaries in the 17th and 18th centuries. Indeed, it should be kept in mind that the "indigenous" Sámi religion at that time had assimilated both Western and Eastern Christian as well as other beliefs and customs "exogeneous" to the Sámi.

In addition, if we contrast indigenous religions with universalising religions such as Christianity, there is a chance of slippage into an unwarranted typologising when spoken of as a general category in this sense. Nevertheless, perhaps the largest challenge with this suggested use is the problem of essentialism. If-in whichever way it is defined-Sámi indigenous religion is viewed as a singular phenomenon covering all Sámi groups, the same questions of local variation, external influences, and "pureness" come into play. One could rather speak of "Sámi indigenous religions" in the plural, but then the contingent nature of this term is compromised. I would settle on the singular form, and instead emphasise variation in time and space by delimiting the use of sources carefully, or when attempting to create a reconstruction of the common core elements in all local variants of Sámi indigenous religions, being overtly explicit and careful about the "educated guesses" to be made of this imagined construction.

To summarise, there is no easy way out. The etic, heuristic terms a historian of religions uses to discuss Sámi religion are all loaded and problematic in one way or another. The way out, as I would see it, is to be explicitly aware of these problems and at the same time respectful to the Sámi whose religious history has all too often been described by outsiders with terms that carry problematic baggage. This should be done while aspiring towards analytical rigor and clarity in term use and awareness of possible points of blurriness and confusion.

My suggestion is to use the concept "indigenous Sámi religion" as a relational category to refer to the practices and beliefs documented by missionaries mostly in the era of colonial activities directed towards the Sámi in the 17th and 18th centuries. I use it as a "geographically and historically contingent relational concept" in the sense Tafjord $(2013$, p. 39) has suggested.

Of course, "religion" is a highly problematic term, and there are also some alternatives to using this term, with suggestions such as "mentality", "world view", or "way of life" being offered in English. One recent trend of avoiding the pitfalls discussed above has been to turn to Sámi terms when speaking of Sámi indigenous religion. In the next section, I will briefly discuss some of the alternatives in North Sámi, mainly basing myself on Jelena Porsanger's pioneering work.

\section{Sámi Analytical Terms and Translations on Three Levels}

\subsection{Translations on Three Levels and the "Indigenous Turn"}

The rise of Indigenous political issues and Indigenous scholarship in the past few decades have resulted in an advancement where local languages, rather than the languages of the majorities or international languages of the academia such as English, French, or German, have been increasingly used in scholarship on issues related to Indigenous peoples. Sámi studies have been no exception, and within the study of religions, especially Porsanger $(2004,2007,2010,2011,2018)$ has contributed with texts in North Sámi, most notably her doctoral thesis, also advocating for the use of Sámi terms as analytical categories in her English contributions.

As I have noted previously, non-Sámi scholars have also begun to include Sámi terms in their vocabularies, as a consequence of the awareness of Indigenous issues. This is most visible in the use of the word noaidi as a replacement of "shaman" and noaidevuohta as a replacement of "shamanism", a process I have called "translating back". This, I have argued, is the result of translations on three levels: the translation of words from one language into another, the translation of concepts from one culture into another, and the translations from natural, everyday language into the analytical language of the academia (Kaikkonen 2019).

The terminology for speaking about "indigenous Sámi religion" in North Sámi has been developed most prominently by Porsanger (2007, p. 4 f.), as she has contributed to the project of making North Sámi a language of the academia, translating terms and concepts between the levels of natural North 
Sámi language use that she calls the level of object language (objeaktagiela dássi) and the analytical level (analyhtalaš dássi).

In her doctoral thesis, Porsanger settled on using the term sámi eamioskkoldat for Sámi indigenous religion, as the concept "emphasises the continuity of Sámi lands and the Sámi people, the central meaning of elders and ancestors as bearers and teachers of Sámi traditions, and the inseparable reciprocity of people and the natural environment." ${ }^{8}$ As the word "indigenous", the North Sámi prefix eami- used for both Indigenous peoples (eámiálbmot) and indigenous religion (eamioskkoldat) has connotations of "home" (ruoktu), according to her (Porsanger 2007, p. 6 f.). Some North Sámi alternatives Porsanger (2018, p. 148 f.) points towards as more problematic are dološ osku, "ancient belief", which to her sounds like an outdated alternative that does not take the processes of change and continuity into account, and the aforementioned luondduosk $u$ which is problematic because of its above-discussed connotations to the nature-culture division and the idea of "primitive nature peoples" and their religions.

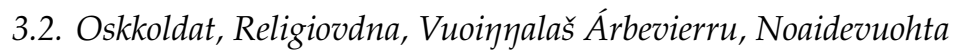

Different critiques of using the term "religion" in relation to peoples whose indigenous vocabulary does not have a corresponding word abound and the Sámi case is no different. Even though the Scandinavian loan word religiovdna has been used since the 1990s, Porsanger (2018, p. 147 f.) rather settles on the Sámi word oskkoldat, derived from the word osku, "belief", "trust", which however also has its origins in Christian discourse and can be considered a translation of Finnish uskonto, derived from the word usko. In order to avert the Christian connotations of religion-derived words, Porsanger has also written about sámi vuoingalaš árbevierru, roughly translated as "Sámi spiritual tradition", although she has not discussed the term as such in more detail.

I believe that we have here a good umbrella term for speaking about Sámi religion for several reasons. First of all, it relates to árbevierru, a Sámi concept which emphasises continuity, but is untranslatable to English as the dichotomy tradition-modernity is awkward for Sámi ways of thinking (Porsanger 2011). Porsanger (2011, p. 240 f.) writes, "A comprehensive Sami concept for tradition/custom is árbevierru (in this case the North Sami term), which contains two interrelated parts, vierru 'mode, custom' and árbi 'heritage, inheritance'", , and continues:

Árbevierru indicates the continuity of the ways people do certain things and adhere to certain values (vierru), which are strengthened and validated by árbi (heritage; inheritance). Customs, innovations, wisdom, knowledge, values, heritage and continuity are inseparable from each other in this way of understanding tradition.

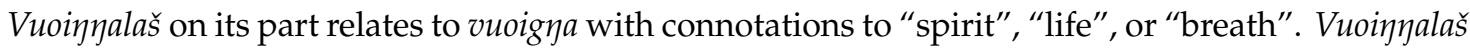
is almost translatable to "spiritual" but with more culture-specific connotations instead of the usual English ones (Kåven et al. 1995, p. 575; Sammallahti 2013, p. 209). One could, for example, speak of the vuoigyas of the noaidis or vuoigyas residing in nature in the natural North Sámi language without connotations to the English word "spiritual", which immediately draws one's attention to "spiritual, not religious" or "spiritual seekers", abundant in the academic discourse on "New Age" and the "religious supermarket". 9

I, therefore, suggest sámi vuoingalaš árbevierru as an umbrella term to replace the term "Sámi religion". Used in this way, sámi vuoinyalaš árbevierru would be an indigenous term used as an etic one to cover the pre-missionary times, the post-missionary ones, as well as the current interest in shamanism and Sámi traditions within Sámi communities, including contemporary forms of Sámi

8 “deattuha sámeálbmoga ja Sámeeatnama jotkkolašvuođa, boarrásiid ja máddariid guovddáš mearkkašumi sámi árbevieru guoddin ja oahpaheaddjin, olbmuin ja luonddubirrasa earukeahtes gaskavuođa." (Porsanger 2007, p. 7) My translation.

9 See, for example, the book New Age Spirituality (Sutcliffe and Gilhus 2013) with an article about "New Age, Sami shamanism and indigenous spirituality" by Fonneland \& Kraft. 
Christianities. Using this term would emphasise continuity, as well as the fact that even if brought from the outside, the Sámi have made different "exogeneous" religious customs and traditions such as Christianity and "core shamanism" as part of their own árbevierru, even though these traditions would have not always been labelled as "religious" by the Sámi themselves-such as was the case with Sámi shamanism until the organised practitioners were forced to incorporate "religion" into their vocabulary quite recently, as Fonneland $(2017$, p. 11; 2018) shows. The term vuoingalaš árbevierru covers at the same time most uses that would be included by the scholarly definitions of religion-for example, those employed in the Sámi case by Rydving (Rydving 2004, p. 7 f.; 2013, p. 393 f.)—but the term does not invoke the problematic Western term "religion" or its Sámi translations.

Being an indigenous term without a heavy previous theoretical baggage, using and developing the technical term sámi vuoinjalaš árbevierru could contribute to a terminology where Sámi matters are discussed with Sámi terms, even by outsiders. Of course, this creates problems for audiences with no understanding of Sámi language. Translations would have to be made on several levels in order to convey the meaning of what the term means in the natural language in order to strengthen its analytical use, but this is a problem that could be tackled by keeping in mind some basic premises of translation theory. Scholarly contributions in other languages than Sámi would then have the task of translating what this term means and defining how it is used in each context as a technical term. This is something scholars do anyway, providing translations that are by default imprecise, but at the same time relevant (see, for example, the introduction to this issue, where the editors refer to James Clifford's ideas on translation).

Indeed, why would central terms related to Sámi religion be translated without critical discussion, while central terms in "world religions" such as püjā or dharma in Sanskrit, dīn in Arabic, or rabbi in Hebrew would remain untranslated? Of course, this would not mean that, in my opinion, we scholars should stop using non-Sámi terms altogether, but rather that we should anchor our term use in Sámi understandings and problematise and define what we mean with analytical concepts such as "Sámi indigenous religion" or "Sámi religion", or words such as "shamanism".

Another word sometimes used about Sámi religion is noaideouohta, often used as a direct translation of "shamanism", in which case it is used not only for the noaidi's trade, but in a wider sense (see Kaikkonen 2019, pp. 559-63). I will not go deeper into the problems with the words "shaman" and "shamanism" in this article than I have done in the introduction, as I have discussed them at length both in my doctoral thesis and in a previous article (Kaikkonen 2019, forthcoming), suffice to say that their use in relation to both Sámi religion in the wider sense, and the trade of the indigenous ritual specialists described in historical sources in the narrower sense, are in my opinion problematic. As I have summarised the problem in the said article:

without critical evaluation the term "shaman" is burdened with ethnocentric biases and theoretical assumptions. It is far from a neutral concept in a Sami context. The outsider definitions and translations of Sami culture in a colonial setting perpetuate ethnic stereotypes and "othering", starting with witchcraft and ending with shamanism (2019, p. 554).

Shamanism as an emic term, describing modern practitioners who call themselves "shamans" and their practices and beliefs as "shamanism" is in my opinion justified and mostly unproblematic. ${ }^{10}$ As Fonneland (2017) has argued, the contemporary shamans have blended Michael Harner's core shamanism with their interpretations of textual and material sources to Sámi indigenous religion, creating a distinctly Sámi version of shamanism (see also Joy 2018, p. 246). I, however, am hesitant as a student of religions to comply with the emic meanings employed by these shamans described by Fonneland (2018, p. 4) who say that shamanism represents a "foundation in all the world's cultures" and that Sámi shamanism represents a continuum from the pre-missionary era. I would rather employ

10 See also (Rydving 2011, p. 9; Fonneland 2017, p. 10; 2018). 
the etic term "pre-missionary noaidevuohta" to describe the noaidi's tasks and trade in the main written sources from the 17th and 18th centuries and reserve the term "shamanism" to describe what I have previously labelled with the etic term "post-secular noaidevuohta" (Kaikkonen 2019, pp. 555-57). This is not to say that there would not be problems with making these divisions between "tradition" and "modernity", a problem I will discuss next.

\section{4. "Neo", “New Age”, “Re-Enactment"-Who Draws the Line?}

In recent times, there has been a growing academic interest in contemporary forms of the sámi vuoingalaš árbevierru, as this special volume entails. Trude Fonneland and Siv Ellen Kraft have contributed to the research on contemporary Sámi shamanism, Tiina Äikäs and Jorunn Jernsletten on sacrificial activities, Cato Christensen has discussed the continuation of Sámi indigenous imaginary in

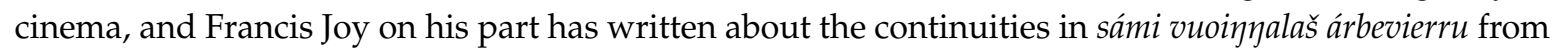
ancient times to the present, to name a few of the recent contributors to the topic's advancement.

One of the topics which have drawn the most attention is Sámi shamanism, developed on Michael Harner's teachings about "core shamanism" and cultivated by the likes of Ailo Gaup and Eirik Myrhaug to become a distinct Sámi phenomenon with not only religious but also political and artistic dimensions (see for example Fonneland 2017; Fonneland and Kraft 2013). This phenomenon that I have decided to label "Sámi shamanism" has most often been related to the "New Age" milieu and spoken of with the etic terms "neoshamanism" or "neopaganism", while the sacrificial rituals have been labelled "re-enactments".

Some of the problems with using the term "neoshamanism" will be taken up next. First of all, it is not something the practitioners themselves often recognize, and many even shun. They most often see themselves as continuers of an ancient technique of shamanism, which is by no means new to them but rather the oldest form of spirituality. According to the practitioners themselves, the essence of "core shamanism" is in bringing into life the most profound and ancient features of human culture, shamanism (Fonneland 2018). If then an outsider defines this as "neoshamanism", it suggests that first of all there is an "old shamanism", and second of all that the practitioners do not practice this "old shamanism" but rather belong to a new religious movement that is no older than the 1970s.

Using the label "neoshamanism" thus includes two questionable assumptions: (1) that there is a phenomenon called "shamanism" "out there", outside of the scholarly debate; and (2) that the researcher holds the power of defining what this true "shamanism" is and what it is not, excluding "modern" practitioners who claim to practice shamanism and deeming them as re-enacters. This stand does not only leave the person who draws the line between "shamanism" and "neoshamanism" with essentialist bias but also ignores the grey area between "true traditions" and "re-enactments". In addition, the division between "tradition" and "modernity"—unfamiliar to Sámi epistemology as noted by Porsanger (2011) — is strongly present in such classifications.

To take some examples from outside the Sámi culture, I would like to draw attention to two cases of rituals among peoples most often labelled "Indigenous" that challenge a straightforward division into "old" and "new" forms of "indigenous religions" (if one wishes to use that label as a category of religions). First, I would like to discuss the case of Khanty and Mansi bear ceremonialism as described by Olga Balalaeva and Andrew Wiget and the "revival" involved. While the traditional ceremonies were banned during the Soviet era and were only remembered by some of the elders in those groups, Wiget and Balalaeva have worked among Khanty and Mansi groups in Russia in order to "save" these ceremonies from dying out. Indigenous actors and scholars have contributed together to communicate some central concepts and traditions between different Arctic groups practicing bear ceremonies in order to fill the gaps created by the forceful oppression of the indigenous ceremonies and rituals by the 
Soviet state. ${ }^{11}$ Would this process that takes up lost or almost lost aspects of an Indigenous culture and reconstructs them with the help of scholarship then count as "re-enactment" in the same way as contemporary offerings at a Sámi sacred site or a Sámi traditional healer speaking of himself as a "shaman"?

The same question could be asked of the yhyakh ceremonies of the Sakha people described by Nikanorova (2019); are these rituals continuations or re-enactments, constructed and based on scholarship in order to serve a political means? The answer is, according to her, both yes and no, and more complex and multifaceted than simply putting a "neo" label on an indigenous tradition from the outside would be. While most scholars who speak of Sámi "neoshamanism" or "re-enactment" would not deem the aforementioned ritual traditions in their contemporary forms as belonging to the "New Age" movement, they might find unity in their political inclinations and their emphasis on indigeneity.

A student of contemporary Sámi religion, or sámi vuoingalaš árbevierru, should, in my opinion, face these questions with a reflexivity and a critical approach that acknowledges the complexities, power relations, and problems of essentialism that are involved when defining the phenomena we study. A self-conscious, critical, and precise use of terms is therefore essential when describing both

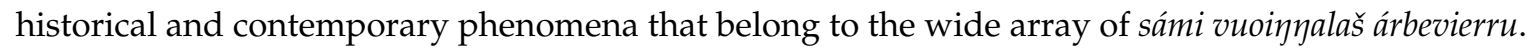

\section{Conclusions}

In this article, I have tried to take up some of the problems a student of religions faces when choosing terms to describe Sámi religion. I have also implicitly suggested that a system for term use can be developed by each scholar on their own, bearing certain points in mind and minding the power that a scholar holds when defining things. Based on these above-mentioned points, I suggest a vocabulary for discussing the Sámi religion that I now open for critique and hope to develop further in the future (Table 1).

Table 1. Suggestions for analytical terms.

\begin{tabular}{cc}
\hline Old Etic Terms & Replacements \\
\hline $\begin{array}{c}\text { Sámi religion, Sámi world view, Sámi way of life, } \\
\text { shamanism, animism, etc. }\end{array}$ & Sámi vuoingalaš árbevierru \\
\hline $\begin{array}{c}\text { Sámi pre-Christian religion, Sámi paganism, Sámi } \\
\text { non-Christian religion, Sámi nature religion, Sámi } \\
\text { ethnic religion, etc. }\end{array}$ & $\begin{array}{c}\text { Sámi indigenous religion (as a contingent, situated } \\
\text { category), Sámi autochthonic religion, Sámi } \\
\text { eamioskkoldat }\end{array}$ \\
\hline Sámi shamanism & Noaidevuohta \\
\hline Sámi neoshamanism & Sámi shamanism \\
\hline
\end{tabular}

Several levels of translation are involved when indigenous terms are used in analytical English, but their theoretical baggage and analytical precision are not as tied to the ever-changing and often competing approaches of the academia. I have decided that the North Sámi term "sámi vuoinyalaš árbevierru" could be used as an umbrella term to cover traditions, customs, and beliefs that have come to bear a distinctly Sámi character, regardless of their origin. These traditions would still fit under most scholarly definitions of religion. Sámi vuoingalaš árbevierru could then be divided into three historically contingent yet overlapping categories: (1) Sámi indigenous religion (SaaN. eamioskkoldat); (2) different forms of Sámi Christianity; and (3) Sámi shamanism (which of course does not cover all contemporary forms of Sámi post-secular practices). The noaidi's trade could be referred to as pre-missionary noaidevuohta, post-missionary noaidevuohta, and post-secular noaidevuohta (or shamanism), as I have suggested previously (Kaikkonen 2019).

11 See the project's website <https://eloka-arctic.org/bears/bear-ceremonialism\#loss-transformation-and-revival> Accessed 28.7.2020. 
Defining and categorising religious traditions from the analytic outside is always a delicate matter and involves balancing on the tightrope between the analytical, generalising, and hypothesising etic mode, and the descriptive, particularising, and specifying emic mode. Accordingly, as we take emic concepts from the level of the natural object language and translate them into the analytical language of academia as etic ones, something is always lost. Still, perhaps useful things are also found in the process and translations provide new insights about non-Western epistemologies for the academic community.

Funding: This research received no external funding.

Acknowledgments: I thank my colleagues and students in both Helsinki, Bergen, and Tromsø for inspiring discussions concerning term use, particularly Håkan Rydving and Bjørn Ola Tafjord, from whom I also received comments for a draft of this article. I would also like to thank the students on the course "Sámi religion" I was privileged to hold twice in Bergen, as well as the students who attended the lecture I held as part of the course "Current Approaches to the Study of Religion" in Helsinki in 2017, where I discussed some of the topics taken up in this paper.

Conflicts of Interest: The author declares no conflict of interest.

\section{References}

Atkinson, Jane Monnig. 1992. Shamanisms Today. Annual Review of Anthropology 21: 307-30. [CrossRef]

Fonneland, Trude A. 2017. Contemporary Shamanisms in Norway: Religion, Entrepreneurship, and Politics. Oxford: Oxford University Press.

Fonneland, Trude A. 2018. Shamanism in Contemporary Norway: Concepts in conflict. Religions 9: 223. [CrossRef] Fonneland, Trude, and Siv Ellen Kraft. 2013. New Age, Sami shamanism and indigenous spirituality. In New Age Spirituality: Rethinking Religion. Durham: Acumen Publishing, pp. 132-45.

Hansen, Lars Ivar, and Bjørnar Olsen. 2013. Hunters in Transition: An Outline of Early Sámi History. The Northern World 63. Leiden: Brill.

Joy, Francis. 2018. Sámi Shamanism, Cosmology and Art as Systems of Embedded Knowledge. Acta Universitatis Lapponiensis 367. Rovaniemi: University of Lapland.

Kaikkonen, Konsta. 2019. From, into, and back: translations of the Sami words noaidi and noaidevuohta in context. Religion 49: 539-70. [CrossRef]

Kaikkonen, Konsta. forthcoming. Contextualising Descriptions of Noaidevuohta: Saami Ritual Specialists in Texts Written until 1871. Doctoral thesis in the Study of Religions currently under evaluation, University of Bergen, Bergen, Norway.

Kåven, Brita, Johan Jernsletten, Ingrid Nordal, John H. Eira, and Aage Solbakk, eds. 1995. Sámi-dáru sátnegirji. Kárášjohka: Davvi Girji.

Nikanorova, Liudmila. 2019. Religion and Indigeneity at Yhyakh. Ph.D. thesis, University of Tromsø, Tromsø, Norway.

Pentikäinen, Juha, and Risto Pulkkinen. 2018. Saamelaisten Mytologia. Kirjokansi 153. Helsinki: Suomalaisen Kirjallisuuden Seura.

Porsanger, Jelena. 2004. An essay about indigenous methodology. Nordlit 15: 105-20. [CrossRef]

Porsanger, Jelena. 2007. Bassejoga čáhci: Gáldut nuortasámiid eamioskkoldaga birra álgoálbmotmetodologiijaid olis. Kárášjohka: Davvi Girji.

Porsanger, Jelena. 2010. Self-determination and Indigenous research: capacity building on our own terms. In Towards an Alternative Development Paradigm: Indigenous Peoples' Self-Determined Development. Edited by Victoria Tauli-Corpuz, Leah Enkiwe-Abayao and Raymond de Chavez. Baguio City: Tebtebba Foundation, pp. 433-46.

Porsanger, Jelena. 2011. The problematisation of the dichotomy of modernity and tradition in Indigenous and Sami contexts. In Working with Traditional Knowledge: Communities, Institutions, Information Systems, Law and Ethics: Writings from the Arbediehtu Pilot Project on Documentation and Protection of Sami Traditional Knowledge. (Dieđut 2011: 1). Edited by Jelena Porsanger and Gunvor Guttorm. Guovdageaidnu: Sámi Allaskuvla, pp. 225-52.

Porsanger, Jelena. 2018. Sámi eamioskkoldaga doahpagastin. Dîn: Tidsskrift for Religion og Kultur 2018: 146-57. Pye, Michael. 1994. Syncretism versus synthesis. Method E Theory in the Study of Religion 6: 217-29. 
Rasmussen, Siv. 2016. Samisk integrering i norsk og svensk kirke i tidlig nytid: En komparasjon mellom Finnmark og Torne lappmark. Ph.D. thesis, University of Tromsø, Tromsø, Norway.

Rydving, Håkan. 2004. The End of Drum-Time: Religious Change among the Lule Saami, 1670s-1740s. Historia Religionum 12. Uppsala: Uppsala University Library. First published 1993.

Rydving, Håkan. 2000. The missionary accounts from the 17th and 18th centuries-The evaluation and interpretation of the sources. In Sami Folkloristics. NNF Publications 6. Edited by Juha Pentikäinen, Harald Gaski, Vuokko Hirvonen, Jelena Sergejeva and Krister Stoor. Turku: NNF, pp. 17-40.

Rydving, Håkan. 2010. Tracing Sami Traditions: In Search of the Indigenous Religion among the Western Sami during the 17 th and 18th Centuries. Instituttet for sammenlignende kulturforskning. Serie B, Skrifter 135. Oslo: Novus Forlag.

Rydving, Håkan. 2011. Le chamanisme aujourd'hui: Constructions et déconstructions d'une illusion scientifique. Études Mongoles et Sibériennes, Centrasiatiques et Tibétaines 42: 1-15. [CrossRef]

Rydving, Håkan. 2013. Sami religion. In The Handbook of Religions in Ancient Europe. Edited by Lisbeth Bredholt Christensen, Olav Hammer and David A. Warburton. Durham: Acumen, pp. 392-407.

Sammallahti, Pekka. 2013. Sámi-suoma-sámi Sátnegirji. Ohcejohka: Girjegiisá. First published 1993.

Sjöblom, Tom. 2002. 'Only a hobo': Heuristic terms in historical ethnography. In Styles and Positions: Ethnographic Perspectives in Comparative Religion. Comparative Religion 8. Edited by Tuula Sakaranaho, Terhi Sjöblom, Tom Utriainen and Heikki Pesonen. Helsinki: University of Helsinki, pp. 126-55.

Sutcliffe, Steven, and Ingvild Gilhus, eds. 2013. New Age Spirituality: Rethinking Religion. Durham: Acumen Publishing.

Tafjord, Bjørn Ola. 2013. Indigenous religion(s) as an analytical category. Method E Theory in the Study of Religion 25: 221-43.

Tafjord, Bjørn Ola. 2016. How talking about indigenous religion may change things: an example from Talamanca. Numen 63: 548-75. [CrossRef]

Tafjord, Bjørn Ola. 2017. Towards a typology of academic uses of 'indigenous religion(s)', or, eight (or nine) language games that scholars play with this phrase. In Handbook of Indigenous Religion(s). Brill Handbooks on Contemporary Religion 15. Edited by Greg Johnson and Siv Ellen Kraft. Leiden: Brill, pp. 25-51.

Thompson, Della, ed. 1998. The Concise Oxford Dictionary, 9th ed. Oxford: Clarendon Press.

Widén, Bill. 1980. Religionsskiftet från hedendom till kristendom bland samerna i Nord-Skandinavien. In Nord-Skandinaviens Historia $i$ Tvärvetenskaplig Belysning. Umeå Studies in the Humanities 24. Edited by Evert Baudou and Karl-Hampus Dahlstedt. Umeå: Umeå Universitetsbibliotek, pp. 263-75.

Winkelman, Michael. 2000. Shamanism: The Neural Ecology of Consciousness and Healing. Westport: Bergin \& Garvey. 